\title{
University Transformations and the New Knowledge Produc- tion Regime in Informational Capitalism
}

\author{
Maxime Ouellet* and Éric Martin** \\ *École des médias, Université du Québec à Montréal, Montreal, Canada, ouel- \\ let.maxime@uqam.ca
}

**Department of Philosophy, Cégep Édouard-Montpetit, Longueuil, Canada, eric.martin@cegepmontpetit.ca

\begin{abstract}
This article examines undergoing transformations in universities in the context of the structural crisis of capitalism, which began more than 40 years ago. This crisis is at the heart of one of the main contradictions of capitalism: while capital needs living labour to produce value, the dynamic of accumulation requires the replacement of human labour by machines. We will show how capital attempts to overcome this contradiction by modifying the nature of knowledge, learning institutions and human beings to turn them into productive investments, whose profitability can be measured. The contemporary mutations of universities are linked to the globalization, financialization and commodification of knowledge. We also observe transformations in universities' institutional arrangements and in individual human consciousness. Our perspective combines institutionalist political economy and Marxian critique of value, showing how material, institutional and cultural transformations are dialectically articulated in a new form of social regulation. We will show how there is a complementarity between the transformations of political, economic and learning institutions and their linkage with a new mode of knowledge production. The general goal being that advanced mastery of knowledge and information will increase the efficiency of the technological and economic system and its endless acceleration.
\end{abstract}

Keywords: Informational Capitalism, Value Theory, University, Globalization, Financialization, Commodification of Knowledge

The purpose of this article is to analyse ongoing transformations within higher learning institutions in the context of the structural crisis that has plagued capitalism in the last 40 years. This crisis is at the heart of one of the main contradictions of capitalism: while capital needs living labour to produce value, the dynamic of accumulation requires the replacement of human labour by machines (Postone 1999; McChesney and Nichols 2016). We will show how capital seeks to overcome this contradiction by altering the nature of knowledge and human beings to transform them into productive investments whose profitability can be measured. We will show how the mutations of contemporary capitalism, described by some as informational (Castells 1996) or as cognitive capitalism (Hardt and Negri 2000), characterised by globalization, financialisation and the commodification of knowledge, are linked to institutional transformations within universities and changes in human consciousness. From a perspective combining both the institutionalist political economy (Mirowski 2011) and the Marxist critique of value (Postone 1993), we will see how material, institutional and cultural transformations are dialectically articulated within a new mode of social regulation. It is important to describe the complementarity between transformations of political, economic and educational institutions, as well as their common belonging to a 
new mode of production of knowledge. It is therefore essential to understand the political nature of these institutional transformations to grasp their ideological basis, which originated in the neoliberal cultural revolution. This 'revolution' consists in conceptualizing economic agents as information processors and the market as a cybernetic mechanism of transmission of information (Ouellet 2016).

First, we will develop a dialectical approach (of Hegelian-Marxian inspiration) to understand the contemporary university, as to avoid the pitfalls of previous critical theories, namely traditional Marxism or postmodern thinking. The second step is to grasp the university's becoming in the context of the structural transformations of late capitalism. Thirdly, we will present the epistemological groundings of the new neoliberal regime of knowledge production, and finally see how it is dialectically articulated with cultural and institutional transformations of universities within informational and globalized capitalism.

\section{Towards a Dialectical and Critical Theory of the University}

Traditional critical theories in the sociology of education field have generally emphasized the role of academic institutions as a mechanism bent on the reproduction of social inequalities. For example, according to Baudelot and Establet, who can be classified as Althusserian-inspired structural-Marxism, it is necessary to criticize the "capitalist school" as an ideological state apparatus responsible for the reproduction of dominant classes (Baudelot and Establet 1971) ${ }^{1}$. Similarly, for Bourdieu and Passeron, education produces symbolic violence and assigns each individual a place in the social field, thus reproducing class habitus (Bourdieu and Passeron 1990). Although relevant, these theories are insufficient in that they are ahistorical and do not account for the systemic transformations, linked to the contemporary mutations of capitalism, that now affect the university. Indeed, they are mainly interested in thinking of schools as an instrument of reproduction of class division. This prevents them from thinking positively of the university ${ }^{2}$ as being initially thought of as a central institution or mediation in the emancipatory project of modernity, grounded in reason. This means thinking of the university as a public sphere ${ }^{3}$, that is, as an institution whose ideal entails the critical discussion between reflective subjects (Giroux 2011). This is why a dialectical approach to the changes of the university, with regard to the

${ }^{1}$ A similar approach can be found in Bowles and Gintis 1976.

2 We refer not to the empirical university, but to the ideal-type of this institution and how it was thought in the modern project. See Freitag (1998).

${ }^{3}$ In saying this, we are not taking a Habermasian stance. We recognise that there are inherent contradictions in the bourgeois subjectivity (which, as Marx pointed out in On the Jewish Question (1844), is ripped apart by an abstract universal ideal of the autonomous citizen and the concrete selfish homo economicus of capitalist social relations). The modern university is also contradictory. It thinks of itself as an ideal public sphere, but it is plagued with contradictions which tend to submit academic freedom to capitalist demands. The problem with the neoliberal university is that it tends to suppress this inner contradiction by openly destroying the traditional ideal mission of the university in the name of immediate adaptation to the organisations of globalized informational capitalism. With Boltanski and Chiapello (1999), we could talk of a new spirit of academic capitalism. In 1968, the artistic critique of the radical students demanded a more horizontal university. As we well show below, post1968 universities integrated this critique by suppressing any vertical reference to their constitutive ideal and adapting horizontally to anything that surrounded them, that is, customers and, especially, economic organisations. 
structural transformations of capitalism, proves necessary today. As Ernest Mandel stressed in the 1970s:

The main task of the university is no longer to produce 'educated' men of judgment and property - an ideal which corresponded to the needs of freely competitive capitalism - but to produce intellectually skilled wage earners for the production and circulation of commodities (Mandel 1975, 262).

The Hegelian Idea, in which reason was to be the motor of historical development, has been subverted: the valorisation of capital replaced reason and became the new Geist, the new substance-as-subject (Postone 1993). Similarly, the modern university of reason ${ }^{4}$ has now become the university of capitalist unreason. After the crisis of Marxism, in the late 1970s and early 1980s, postmodern thought emerged (Lyotard 1984). This new, non-dialectical approach does take note of the colonization of the university by the system, but considers it as inevitable in the era of the 'end of grand narratives'.

Since the institution - initially dedicated to seeking universality and truth - has been absorbed by the system, critical people can only, according to a postmodern perspective, rely on defending particularity or seek refuge in transgressive language games to resist or try to outfox capitalism, without any hope of ever actually transforming it (Readings 1997). These approaches abandon any reference to reason and truth, which then become synonymous with capitalism, and fall back upon the defense of the infinite plurality of discourses.

Moreover, the postmodern left has provided the privatization of knowledge with academic legitimacy by deconstructing the idea of science as a public good. Indeed, according to economic historian Philip Mirowski, the actor-network theory developed by Michel Callon and Bruno Latour (Callon 1988) played a role in the legitimation for the privatization of knowledge in American universities. According to Callon and Latour, nothing in science prevents it from being transformed into a commodity, as Philip Mirowski notes, quoting Michel Callon:

"[...] there is nothing in science that prevents it from being transformed into a merchandise". Because nonexclusion was reportedly not proving to be such a problem, and nonrivalry did not really exist in science, "scientific knowledge does not constitute a public good as defined by economic theory". Far from economists politically displacing sociologists, it seems neoliberalism had taken root in the most avant-garde precincts of science studies, gussied up with

\footnotetext{
${ }^{4}$ This does not mean that we should only seek to save modern reason from the unreason of capital. Indeed, as Adorno and Horkheimer (2002) well understood, we must develop a critique of the bourgeois and instrumental understanding of reason that dominated modernity, in that it is linked to the market form of social relations. This critique, as we shall argue, must not be carried out in the name of postmodern irrationalism or anti-foundationalism, but in order to save reason from its own pitfalls, relying not only on its negative critical moment, but also and as an essential means of thinking the need for roots in the positivity of the concrete world.
} 
the seemingly non economic terminology of actants, rhizomes, networks and parliament of things (Mirowski 2011, 66).

Anti-universalism, anti-humanism and anti-essentialism, which are the foundations of postmodern relativistic epistemology, are part of a new social ontology that expresses itself as much in dominant neo-liberalism as in the theoretical discourse of the postmodern left (Mirowski 2013). Current "critical" research that insists on the subjective resistance of actors or identities while rejecting any possibility of analysing society as totality, reproduces the ontological foundations of neoliberal practice in the field of pseudo-critical theory. This is a good illustration of the hegemony of neoliberalism: the inability to 'think outside the box' or frame of dominating forms of representation. This is why it is necessary to re-articulate a Hegelian-Marxian critique of the university, which should, following Adorno and Horkheimer (2002), think of itself as a dialectic of reason.

Traditional Marxist ${ }^{5}$ approaches understand knowledge in predominantly instrumental terms. Capitalism no longer treats knowledge as a means of access to truth, but merely as a factor of production and valorisation. Pseudo-critical approaches are incapable of considering the dialectical relationship between forms of social relations and forms of knowledge. They are mainly interested in criticizing class relations, and thus mainly consider the distribution of knowledge as a variable one can use to explain social differentiation or the distribution of "symbolic capital" (Bourdieu and Passeron 1990). Postmodern approaches go even further by separating knowledge and truth, and reducing all discourses to moves in a power game. Rather, we believe that forms of subjectivity, knowledge, culture and social relations should be considered as being part of a "relation of objectification"6 (Freitag 2002). That is, a type of society has a given moment in history, is structured, as a whole, by specific forms of culturalsymbolic and political-institutional mediations. These mediations shape the form of subjectivities, the type of knowledge or culture, the type of institution, and the type of social relationship that will prevail in that given form of society. According to Lukàcs (1975), one cannot understand the reified relation to knowledge, reduced to instrumental reason, and to the institution that is university without developing a theoretical understanding of the social mediations that are specific to the capitalist form of society.

Our approach (Martin and Ouellet 2014), based on the "radical critique of value" (Wertkritik) (Larsen et al. 2014), undertakes a categorial critique of capitalist domination in order to go beyond the limits of postmodern approaches, which merely pit the particular against the universal, but also the limits of traditional Marxist approaches whose analysis of capitalism is mainly centred on class relations. According to our approach, categories of thought are also categories of social practice and are determined by forms of mediation specific to a given type of society. Knowledge, institutions and the forms of social objectivity and subjectivity are all mediated by the social totality. In the same way, in order to criticize the contemporary university - the conception of knowledge which prevails inside it, and the subjectivities who inhabit it more attention must be paid to the manner in which these subjects and objects are

${ }^{5}$ On the distinction between traditional and critical Marxism, see Postone (1993).

${ }^{6}$ According to Freitag (2002), the objectification relation is understood in Hegelian terms as (S-m-O), where both the subject and the object are shaped by the mediation, itself understood as a moment of social totality. 
determined by the form of social mediation, and the relation between this form of mediation and late capitalism understood as a whole or totality.

This is why the capitalist university and the instrumental or utilitarian knowledge it produces cannot be understood outside of a historical sociology which seeks to explain the failure of the modern project and the advent of a society dominated by commodity fetishism, whose triumph means the entry into postmodernity, an era dominated by informational capitalism. The modern university was conceived in ideal terms as an institution dedicated to Bildung, allowing society to reflect critically on itself, as part of a wider democratic, public and political sphere. Our work shows how this institution is gradually becoming an organisation ${ }^{7}$, serving the reproduction of the advanced capitalist system, dominated by techno-science and cybernetic thought. The university no longer ${ }^{8}$ serves the democratic project or the "self-institution of society" (Castoriadis 1997); it is now thought of only as a hub for technological innovation useful for the valorisation of capital.

In this perspective, we can understand how certain forms of subjectivity, conceptions of knowledge or institutions (in particular universities), as well as theoretical trends, may emerge or disappear according to changes in the dominant or overarching forms of social mediation. Following critical neo-Gramscian theorists (Cox 1987), it is possible to argue that there is a dialectical interrelation between the predominant modes of economic production, institutions, forms of human consciousness or dominant theories in academia, and the type of subjectivity that is hegemonic at a given time. As we will argue below, it is therefore necessary to historicize theoretical production itself insofar as it expresses a specific social form and a specific historical moment.

\section{The Transformations of the University in Late Capitalism}

In order to grasp the transformations of the university in the context of informational capitalism, it is first necessary to grasp the fundamental changes that have taken place within economic institutions in the era of late capitalism. The corporation, which is characterised by the separation of control and ownership, replaces the classical figure of the bourgeois who owns the means of production, and becomes the main institution within the capitalist mode of production (Berle and Means 1968). According to Baran and Sweezy, this institutional transformation was insufficiently taken into account by Marxist economists. This requires a reformulation of Marx's original framework of analysis, designed in the context of liberal capitalism where the market was the main form of central mediation (Baran and Sweezy 1966). The rising of the

\footnotetext{
${ }^{7}$ An institution is governed by a reflective purpose that aims for an ideal (a university should transmit culture, for example) whereas an organisation is merely an aggregate of individuals who aim to maximize efficiency in order to reproduce and extend the reign of this same organisation (for example, a capitalist corporation). See Freitag (1998).

8 This doesn't imply the empirical university actually ever did serve such a purpose. We are here comparing the modern ideal of the university with its current ruin. We are not therefore suggesting the Fordist university is the model we should go back to. Indeed, the Fordist university, although it had in some cases a relative autonomy from the market, was in fact, in general terms, already seen by large economic institutions like the OECD as a means to increase national production (see Papadopoulos 1994). The relative autonomy we are referring to disappears in the neoliberal university. For example, STEM (Science, technology, engineering and management) sectors were already well embedded in the capitalist accumulation process in the capitalist era. Now, humanities are also being integrated in the socalled 'creative economy'. See Jessop (2017).
} 
organic composition of capital, which leads to the tendency of the rate of profit to fall, was replaced by the more perilous problem of overproduction induced by intercapitalist competition. Planned obsolescence, advertising and marketing then all appear as necessary mechanisms to absorb the excess of surplus-value within a deeply irrational mode of development. The development of the financial, insurance and real estate sectors, as well as the mass media (Smythe 1977), also became important industrial sectors employing an increasing mass of workers to compensate the contradictions of capital.

The discourse on 'knowledge-based economy', the very basis for contemporary theses on informational capitalism, finds some of its origins in the "managerial revolution" (Burnham 1960), although the exact expression was not yet used at that time. The rise of the managerial class is made possible by dispossessing workers of their know-how, and the latter recodification of this knowledge by the bureaucratic apparatus of the capitalist enterprise, under the aegis of the scientific management of labour initiated by Taylor (Braverman 1974). The role of this techno-structure was to put a maximum quantity of information in circulation, so as to make the most efficient decisions (Galbraith 1967).

In the Fordist context, the university and the education system occupy a central place (Noble 1977). Contrary to what the strictly negative critics claim (Althusser 1976; Bourdieu and Passeron 1990), schools are not merely an instance of reproduction of class domination. The relationship between the state, university and corporation, far from corresponding to their current fusion in the neoliberal regime, still depended on a relative autonomy being granted to educational institutions.

From a political point of view, the massive entry of students into universities in the post-war era occurs in the context of a capital-labour compromise and its institutionalization in the American New Deal (Cohen 2003). The democratization/massification of higher education is part of the extension of certain social rights which form the basis of the welfare state (Marshall 1963). Indeed, the democratization of higher education can be understood as the result of a struggle for wider access to education. But this reform, from the point of view of capital, was also necessary to maintain the dynamics of value-production and to produce a type of individual adapted to the logic of overconsumption/overproduction of the Fordist era. This mode of regulation was also characterised by the explosion of the services sector, which was dependent on the advances of the welfare state and the bureaucratization of public and private organisations.

It also allowed for the formation of a middle class made up of professional managers (Bell 1973). In addition to the technical sectors directly related to capitalist accumulation, such as industrial engineering, social sciences developed at that time in American universities, notably thanks to the philanthropic funding of private foundations (for example, the Rockefeller, Carnegie and Ford foundations). The philanthropic funding of social sciences was more specifically aimed at depoliticizing their subversive potential by promoting the use of empiricist methods. Administrative 'sciences', especially marketing and management, formed the basis of a technocratic science that could increase the possibilities of social control (Noble 1977).

The Fordist era mass university was producing technocrats who would orchestrate national development, relying in particular on the positivist scientific ideas of the time. Still, the university enjoyed a relative autonomy based on a conception of knowledge as a public good. This maintained a certain type of distance between academic research and the corporation. As Mirowski points out, during the Cold War, the academic research was thought of as being performed in a nationalized system by self- 
less professors valuing integrity, taking pride in academic freedom and displaying somewhat of a disdain for the market:

It was only within the Cold War regime that "academic freedom" became invested with sufficient gravitas to actually be deployed in an effective defense of the system of academic tenure - something we can now appreciate in the era of its disappearance. The researcher was said to have only to answer to his disciplinary peers, or in the last instance, to his individual conscience, and to feel an enlightened disdain for the hurly-burly of the marketplace at least until the DARPA grants officer came to call (Mirowski 2011, 114).

This understanding of knowledge, shared at the time by the majority of economists, can explain the hegemony of the Keynesian paradigm and its synthesis with the neoclassical school, as formulated by economist Paul Samuelson (Dostaler and Beaud 1995). In fact, the positivist Marxist conception of labour-value and the developmental paradigm belong to the same social imaginary as the social engineering promulgated by the synthesis between Keynesianism and neo-classical doctrine. Looking at ideas and thinking, hegemony is to be found in the common aim shared by all these doctrines: to stimulate effective demand through the recognition of the value of work and the increase in the purchasing power of consumers.

\section{The Commodification of Information and the New Knowledge Production Re- gime in Globalized Informational Capitalism}

The crisis of Fordism on the global scale at the turn of the 1970s resulted in a restructuring of the dialectical articulation between the productive forces, institutions and subjective forms of human consciousness (Cox 1987). The traditional explanation of this period finds the reason for the restructuring of the capitalist world order in the new hegemony of neoliberal ideas (Rupert 2000). This analysis does not, in our view, adequately explain the nature of the neoliberal project. In this section, we will outline the constitutive dialectic of the neoliberal university, that is, the mediation between its particular conception of knowledge and its general institutionalization in the new globalized system of privatized knowledge.

The traditional critique of neoliberalism describes this philosophy as a return to a certain form of classical liberalism and its doctrine of laissez-faire. This superficial reading does not allow a real understanding of the essence of neoliberalism, which institutes a paradigmatic revolution transforming the classical liberal conception of the market. Indeed, neoliberalism re-defines the market as a cybernetic system that transmits information to economic agents, who are themselves thought of as information processors (Mirowski 2013). According to neoliberals, it is impossible for a subject to know all the information held by other particular individuals. That is why the market is considered superior to planning. In the neoliberal conception, knowledge cannot be assimilated to a public good. It is rather a commodity like any other, whose value comes from the fact that it makes it possible to reduce the uncertainties coming from a hyper-complex world, whose totality cannot be known or understood by any subject.

The paradigmatic market revolution understood as a cybernetic system of information transmission was first outlined by Hayek in an article entitled, "The Use of 
Knowledge in Society" (Hayek 1945). This text, a sort of manifesto for knowledge economy, prefigures postmodernity, in so far as it already announces the fall of reason and its inability to synthetically grasp reality (for example, the crisis of grand narratives in Lyotard). The neo-liberal epistemological revolution then went on to be an inspiration for public policies in the majority of industrialized countries, notably pertaining to research financing. These policies were particularly inspired by a World Bank consultant, Michael Gibbons, who argues that in the knowledge-based economy, the "mode of production" of knowledge must be transformed. Traditional knowledge was produced in universities according to a model called "hierarchical", based on a debate within the scientific community to evaluate the validity of knowledge on the basis of a truth criterion. The new "mode of production of knowledge" (or 'Mode 2') advocates de-hierarchizing the production of knowledge insofar as it is no longer the scientific community that must judge the validity of knowledge. It is rather the ability of knowledge to find a practical application in the external environment (i.e. the economy) that becomes the criterion determining their validation (Gibbons et al. 1994).

From the 1970s onwards, the cybernetic conception of the market, picked up by most neoclassical economists, became the dominant paradigm in "economic science" (Mirowski 2000). The subjectivist theory of value understood as liquidity, which is at the basis of the speculative mechanisms of price formation in the market sphere in the present financialized capitalism, corresponds, from an epistemological point of view, with the equally subjectivist and post-modern theories marked by antifoundationalism, anti-essentialism, and anti-universalism. Indeed, the marketefficiency theory (Bryan and Rafferty 2013), the basis for the evaluation of derivative products in financial markets, argues that the value of a security on the stock exchange reflects the information possessed by economic actors. In this sense, contemporary theories on "digital labor" (Fuchs 2013) must be related to the current system of financial accumulation (Ouellet 2015). In a context of increased economic risks associated with uncertainty in a global financial universe, new, more complex and abstract financial products such as derivatives have been created. In financialized capitalism, risk in fact becomes a new form of social mediation. Based on information and digitized financial data (Manzerolle and Kjøsen 2012), risk is linked to the mediation of social relations by abstract labour. In the same way that the exchange of any commodity is based on the abstraction of labour, the possibility of exchanging derived products stems from the abstraction of the specificity of a multitude of particular risks, which, in their very essence, are in fact immeasurable. The abstracted risk is subsequently taken to be measurable and decomposable into homogeneous units that can thereafter be traded on financial markets (Lipuma and Lee 2005).

Thus, in advanced capitalist societies, there is a profound change in the way in which social reproduction takes place, a transformation, which also affects the subjectivity of the actors operating within universities. In the context of so-called informational capitalism, social reproduction no longer relies solely on the relationship of wage domination, but rests largely on the existence of credit. This does not mean that work as a central form of social mediation and domination has disappeared, but rather that its role is transformed. Employment now has the primary function of obtaining a minimum wage to acquire sufficient financial credibility in order to access credit and repay a portion of one's debt. Reproduction of the labour force thus becomes itself a source of surplus value, since this surplus value is now captured before entering the relationship of wage domination (Bryan et al. 2009). This surplusvalue takes the form of an annuity capital manages to skim from the monthly repay- 
ment of the debt of employees and students. In this context, the individual is forced to act as an entrepreneur-of-himself who manages his risk level in a context of widespread financial insecurity. This imposed management of financial risk ensures that human beings themselves become and act as a form of capital, as in the theory of human capital (Becker 1964). This ideology serves as justification for the neoliberal conception of the entrepreneurial subject. Moreover, the concept of the individual, who manages her/his risks as a business, standardizes the use of student debt under the false pretence that students will be able to reap larger future income streams by investing more in their human "capital" (Martin and Ouellet 2011). This institutional complementarity between knowledge and finance risks, according to some economists, is creating a new speculative bubble threatening to burst: the "student debt bubble" (The Economist 2011).

The hegemony of the neo-liberal conceptualization of knowledge must be understood in the context of the crisis of the predominant institutional form in late capitalism, that is, the corporation. In addition to being characterised by the separation of ownership and control, it is based on a new conception of property which is defined by its intangibility (Bichler and Nitzan 2009). Intangible assets are the immaterial assets of businesses that allow them to harvest future revenue streams through a monopoly market control strategy (patents, trademarks, agreements with other corporations, or with governments). In a failing Fordist accumulation regime, the strategy for reviving American corporations was, on the one hand, to redeploy its activities by developing their intangible capital and, on the other hand, to subcontract industrial production to developing countries.

In a context where financial markets demand rapid returns, firms have adopted a range of management techniques such as competitive engineering, subcontracting, downsizing, teamwork, decentralization, and so on. The pyramidal and hierarchical business has been replaced by the networked firm, whose components are constantly reinventing themselves in response to market demands. The strategy chosen to overcome the crisis of the Fordist mode of regulation was thus to transform the firm into a cybernetic organisation. This transformation has enabled the company to grow its image-capital by aiming communication flows towards its shareholders (projecting a financial image), employees (internal image), consumers (brand image) and citizens (the civic image) (Mattelart 1991). This communication strategy was also a response to criticism of the hierarchical structure in the Fordist mode of regulation, seen as an obstacle to the liberation of individual capacities (Boltanski and Chiapello 1999).

This major restructuring within corporations coincides with a crisis in the education sector characterised by a decrease in student enrolment and a withdrawal of public funding from universities. To mitigate this decline in public funding, the solution advocated by many universities will be to link them more closely with businesses (Slaughter and Leslie 1999). In the context of rising demands for shareholder value, companies asked to generate short-term returns will see universities as a privileged place to outsource their research and development departments. As R \& D investments are deemed too risky, the new strategy lies in offloading financial risk on public research and privatizing profits in the form of patents. These patents in turn make it possible to generate value from intangible capital in the stock market (Mouhoud and Plihon 2009).

The new global knowledge production regime is intimately linked to the restructuring of the corporation and the university following the crisis of the Fordist regime. 
Based on the open science ${ }^{9}$ principle of the Fordist regime, the intellectual property rights regime was radically transformed in the United States when the Bay-Dohle Act was passed in 1980 (Mirowski 2011). This law allowed the granting of patents and the commercialization of publicly funded research developed in American universities. The Bay-Dohle act also made possible an extension of intellectual property rights in new fields where commercial monopoly was traditionally forbidden in the name of open science, for example information technology or the study of living beings (Zeller 2008).

Moreover, intellectual property rights are closely linked to the knowledge economy and to the financialization of capitalism. Financial capital extracts value from social activity in general, for example in digital labour. The norm of shareholder value which requires a steady increase in profitability - imposes its rentier logic on knowledge, which becomes a key sector of capitalist accumulation (Vercelonne 2004). High-tech firms, whose profits rarely match their market capitalization, accumulate capital in the form of intangible assets generated by intellectual property rights. This monopolization of knowledge is at the heart of the privatized intellectual property rights regime and allows financial capital to extend the appropriation of social production in a renewed form of primitive accumulation (Harvey 2003).

As noted by Orsi and Coriat, the predominantly financial accumulation regime stems from an institutional complementarity between deregulation in the fields of knowledge and finance (Orsi and Coriat 2006). In the 1980s, financial deregulation allowed loss-making firms that had revenues from their intangible assets - primarily generated by intellectual property rights - to enter the stock market. In addition, the deregulation of the rules governing pension funds allowed them to invest in high risk markets, a practice previously prohibited by Prudent Man Law. The introduction of the liquidity of these pension funds in risky markets has thus contributed to the expansion of the financial bubble of the "new economy", in which new firms (Oracle, Google and Yahoo) then appeared (Orsi and Coriat 2006). The new globalized production regime has spread globally and has become institutionalized with the ratification of trade-related intellectual property rights (TRIPS) at the WTO in 1994. This is the first general agreement that deals with communication, information, finance and knowledge sectors as global trade issues (May 2000). This agreement has institutionalized the logic of exploitation specific to "digital labour" on a global scale, as it legalizes the separation between the producer of information and the holder of the means of production.

\section{The Neoliberal Restructuration of the University and the Transformation of the Academic Subjectivity}

The objective changes we identify in the academic sector stem from a change in the overarching social mediations, which organise society understood as a totality. This also implies a change in the subjective form that will be produced socially as well as by the university. The modern university participated in a politico-institutional mode of reproduction of society (Freitag 1998; 2002). Since then, societies have mutated in the direction of a new mode of reproduction dominated by self-reproducing systems. To make things short, we can call this mode "postmodernity", understood as Jameson says, as the "cultural logic of late capitalism" (Jameson 1991).

${ }^{9}$ According to science sociologist Robert K. Merton (1942) the ethos of open science has the following characteristics: communalism (management of science as a public good), universalism, moral integrity, selflessness, organised sceptical thinking. 
Each mode of production and social reproduction is characterised by a specific form of social mediation and by a specific type of technical mediation (Innis 1950). It is therefore problematic to purport technology could be neutral. Just as Marx understood machinery as the specifically capitalist type of technology, we argue that digital technology is the specific form of globalized neoliberal informational capitalism (Ouellet 2016). Initial observers of this transformation, like Lyotard (1984), failed to see the dramatic implications of this change and naively celebrated the democratic potential of computers and free access to databases ${ }^{10}$. Alas, they were blinded to the fact that the new digital (Hassan 2017) and virtual university (Robins and Webster 2003) were in fact specific institutional expressions of the neoliberal transformation of society and were also producing new entrepreneur-subjects adapted to this dynamic (Bissonnette and Laval 2017). Postmodern enthusiasts such as Lyotard failed to see that the new technology itself was an expression of capitalist alienation and thus participated in the propagation of the new ideology of legitimation of capitalism by entertaining false hopes that this technology could be used to build a new domination-free world (Barbrook and Cameron 1996).

Reality was much less romantic. In an attempt to respond to the crisis of Fordism and the ensuing "great devaluation" (Lohoff and Trenkle 2014), the transnational capitalist class (Sklair 1991) tried to use knowledge to catalyse and stimulate technological innovation and the valuation of capital. The link between university and corporations is institutionalized with the introduction of new governance measures inspired by the business sector (Martin and Ouellet 2012), although with a notable difference: in the corporation, managers sought to establish pseudo-horizontal forms of decisionmaking, whereas in the university, traditional collegiality between teachers is replaced by vertical, hierarchical and authoritarian forms which concentrate the executive power at the pyramid's summit. In globalized capitalism, the classical, or even Fordist, institutional model of the university, considered too sluggish to adapt to the new economy, is to be replaced by new "agile" universities (Gillies 2011) who are expected to be hyper-reactive, capable of adapting and anticipating changes in the systemic technical and economic environment. In return, commodified knowledge is called upon to lubricate the process of valuation, to create new technologies in the 'edge' sectors (biotechnology, communication, artificial intelligence, nanotechnology, etc.). These institutional transformations, linked to capitalist globalization, lead to the creation of a similarly "globalized university" (Martin 2016). They also imply changes in the very definition of knowledge, as well as the production of subjectivities (professors, students, etc.) that are now expected to act in the university as entrepreneurs managing their own human capital or as consumers of skills. This transformation of the status of knowledge is clearly illustrated in the new dynamics of Big Data, which leads to the alienation of all know-how, skills and theoretical knowledge, and therefore to generalized proletarianization (Stiegler 2012). According to Chris Andersen (2008):

This is a world where massive amounts of data and applied mathematics replace every other tool that might be brought to bear. Out with every theory of human behavior, from linguistics to sociology. Forget taxonomy, ontology, and psychology. Who knows why people do what they

${ }^{10}$ Even now, some contemporary critics such as Gary Hall (2016) seek to use these technologies to invent new economic models through 'affirmative disruption'. 
do? The point is they do it, and we can track and measure it with unprecedented fidelity. With enough data, the numbers speak for themselves.

In the same way as it profoundly modifies the role of the former welfare state of Fordism, educational neoliberalism transforms the internal "DNA" of the university (Christensen and Eyring 2011). This new system of normativity and its ideological discourse of justification is disseminated by the World Bank and the Organization for Economic Cooperation and Development (OECD). The aim of these transformations is to take the institutional model of the university, understood as a public service geared (at least in principle) towards the idea of the "common good" within a collectivity, and replace it by a new "university-organization" (Freitag 1995). The new University Inc. is post-national, connected to other corporate organisations and dominated by private interests: interests of industry actors, student-consumers, professorsentrepreneurs, families wanting to reproduce their class position, etc. The concept of "internationalization" seems to refer to international cooperation (i.e. helping third world children). Indeed, it rather signifies that the criteria for what is considered a relevant production of knowledge will now be dictated by the new "higher education global market" which is being set up. As Michael Gibbons points out: "Relevance is going to become something that will need to be demonstrated, not just once but on an ongoing basis. Economic imperatives will sweep all before it and "if the universities do not adapt, they will be by-passed" (Gibbons 1997, 2). This could lead to complete university privatization (market model), publicly financed institutions functioning with market mechanisms (quasi-market model) or a mix of both private and public "providers" in interplay, as currently projected in the UK.

\subsection{The World-Class University}

University rankings are pushing universities around the world towards a conformist behaviour, in favour of imitating what the World Bank calls the "world-class university" (Salmi 2009). Everywhere, universities are forced to abandon their traditional form to copy British or American elite universities, known as 'research-intensive', which are always peculiarly positioned at the top of said rankings.

The new globalized universities are thought of as sluggish organisations in need of a major internal restructuring in order to concentrate their resources on excellence niches, enabling them to succeed in the new cross-border (denationalized) and commodified education market, where non-profit actors will compete with new forprofit providers, all thanks to free trade agreements on the commercialization of services (OECD and World Bank 2007). The university is no longer understood as a national public institution, but as a transnational bureaucratic organisation (Readings 1997).

The denationalization (Friedman 2002) of the universities is also based on the promotion of computerized and virtualized "disruption technology" (Christensen and Eyring 2011), that is Massive Open Online Courses (MOOCs), in what could be named a movement of Uberization of the university ${ }^{11}$. Competition in a new borderless market means that smaller institutions and/or those located on the outskirts of major centres will be disadvantaged in favour of major research universities in a given country, which will concentrate most of the funding (for example, the Russell

\footnotetext{
${ }^{11}$ See Robert Hassan (2016).
} 
Group in the UK), unless, as we see in France with the COMUE ${ }^{12}$, we engage in mergers between institutions. The myth of the class-blind republican school (already debunked by Baudelot and Establet (1971), who showed how schooling served to reproduce class divisions and capitalist social relations) now leaves room for a transparent and shameless two-tiered education system separating elite and peripheral schools.

\subsection{The Student Customer and the Entrepreneur-Teacher}

Foreign students are now seen as an export sector of the economy. For example, a British ${ }^{13}$ report estimates the "value of UK education exports" at $£ 14,1$ billion (Department for Business, Innovation and Skills 2011). The Minister of Education in 2013, David Willetts, said: "There are few sectors of the UK economy with the capacity to grow and generate earnings as impressive as education" (UK Government 2013). Competition among institutions at the national level is also encouraged, notably through the introduction of the new Teaching Excellence Framework (TEF) and the introduction of private "new providers" into the academic "market" (Cruickshank 2016). Teachers are transformed into providers of skills leading to employment, and student-customers are surveyed to determine their satisfaction. Subsequently, committees, including industry players, will assign a rank (bronze, silver, gold) to each university, which will serve to rank low-cost and elite universities that will then obtain permission to increase their (already high) tuition of $£ 9,000$ (Adams 2015), since they will be able to claim that they produce the best suited "human capital" to please the needs of the economic environment. This implies a higher level of student debt, which also contributes to the redefinition of the student as a customer, since s/he can now argue that s/he pays and gets into debt to be in the classroom, which entitles her/him to demand a certain return on her/his investment in terms of value-formoney. Isn't the customer always right?

Research professors/entrepreneurs are increasingly recruited according to their ability to be international stars, attract clientele and, mainly, research grants. The duration of probation is increased, and in some cases tenure is now even being abolished in order to stimulate research productivity. Shanghai Jai Tong University (Zhang 2014), China, seeks to emulate the North American model and become part of the world-class research universities club. It has introduced new recruitment procedures for professors: one can reach a permanent position after six years under supervision and two evaluations by an international committee. Promotions and salaries are re-evaluated every three years using performance indicators. Some researchers must make up part of their own salary with research grants. By 2018, faculty members who do not fit the new model (for example, those who 'only' teach and do no subsidised research) will have to leave the university or will be reassigned to non-teaching jobs (Martin 2016).

12 The French Communauté d'université et établissements (COMUE) designates a regrouping of several institutions under one common organisational body. Universities can also go further and merge to create larger bodies in order to obtain world-class proportions and secure research grants.

${ }^{13}$ We recognise, with Jessop (2017), the varieties of academic capitalism, we identify a general trend towards the imposition of a unique globalized university model (Laval et al. 2011), inspired by American academic capitalism. This tendency entails projects to increase tuition fees in many localities: Quebec (Martin and Ouellet 2011), Chile (Martin 2011), France (Collectif ACIDES 2015), UK (Cruickshank 2016) etc. It also leads to changes in governance, quality evaluation, pedagogy and to the commodification of research. 
The relevance of a professor's knowledge is no longer measured in terms of scholarly knowledge of a given field, but by its ability to enter in 'partnerships' with the industry in order to transfer knowledge or patents towards businesses (alternatively, the researcher can create his own spinoff company). Changes in governance reduce the power of teachers and increase the power of industry 'partners' in administrative bodies. Teachers are increasingly subject to evaluation and quality assurance mechanisms, new forms of control that value professor-entrepreneur behaviour and marginalize those who 'only' teach. What was once the main function of a university professor is now thought of as inefficient and outdated. Some 'professors' no longer teach at all, as they are too wrapped up in managing their own little research start-up. This, of course, raises concerns about academic freedom, since the professor who fails to be recognised as productive (generating research valued by the system or skills directly connected with employability) eventually risks being ejected from the "organization". Otherwise a university with poor performance ratings could itself be deemed non-efficient and could see its accreditation withdrawn, as is projected in the UK. Uberization, in general, means that previously relatively stable jobs will be technologically disrupted and workers will be thrown into job insecurity. The education sector reproduces this scenario: devaluation of academic work, automation of this work and general alienation of the relation to knowledge (Noble 1997). In the end, academic workers, just like all other workers, will end up as precarious waged slaves for the great tech corporations who are taking over the classroom (Singer 2017).

\section{Conclusion: The Contradictions of Informational Capitalism}

As we have shown in this article, the mutations of informational capitalism have led to the modification of the nature of knowledge and of human beings in order to transform them into productive investments or capital. The transformations of knowledge, academic institutions and academic subjectivities must be analysed dialectically by linking them to material transformations. Without such an articulation, it is difficult to understand how the new mode of social regulation deployed by neoliberalism and financialized informational capitalism. These transformations are insufficiently explained by the traditional critical approaches in the sociology of education, which mainly study schools as a mechanism reproducing class divisions. Postmodern theoretical approaches (Lyotard 1984; Readings 1997) rely on the transgressive fluidity of individual language games (or sheer irrationality) to resist an institution conceived as irremediably colonised by the instrumental rationality of the system.

These theories are insufficient and unsatisfactory. This is why we have argued here in favour of a dialectical and critical theory of the transformations of knowledge and universities, a theory that is capable of linking these transformations to the mutations of late capitalism, the extension of neoliberal rationality and the general tendency of subsuming society (understood as totality) to the mediation of abstract value, commodities, abstract labour and money, criticising these alienated categories of social practice without abandoning the aim of modern reason and the "university principle" (Prado 2009) . As Herbert Marcuse said: "if the abstract character of the refusal is the result of total reification, then the concrete ground for refusal must still exist, for reification is an illusion" (Marcuse 1964, 260). Therefore, alienation must be negated and refused, but the critique of fetishized mediations does not imply a retreat into some irrational subjectivism; it rather stems desire to institute unalienated mediations grounded in what can be salvaged in what Hegel calls the "concrete universal".

Moreover, the most recent economic crisis has shown the limits of the neoliberal accumulation strategy based on mass indebtedness, financial speculation and the 
commodification of knowledge. Capital in crisis desperately seeks new sectors to expand into. According to the transnational elites, the solution to the crisis would be to intensify the ties between universities and corporations in order to accomplish the "fourth industrial revolution" based on the convergence between the physical sciences, digital technology and biology (Schwab 2016). This will further accelerate the contradictions of informational capitalism, which are based on the dialectical interrelationship between the mediations of labour, wealth and value in an economy that is now knowledge-based. Indeed, from a cultural point of view, the neoliberal university rests on fundamentally contradictory reasoning. It is based on a discourse that considers the market as the most effective mechanism for transmitting information, yet it ultimately leads to ignorance (Mirowski 2013, 81). The privatization of knowledge within the neoliberal university thus leads to the dissolution of its founding ideal: educating knowledgeable citizen with sound judgement.

In economic terms, as Marx emphasized in the Grundrisse, increasing technological progress implies that the production of material wealth requires less and less human labour throughout. At the same time, capitalism needs to produce value by mobilizing living labour (Marx 1969, 342). According to a report published by the World Economic Forum, the Fourth Industrial Revolution, propelled by Big Data and the "Internet of Things", will lead to the loss of 5 million jobs within five years (World Economic Forum 2016). According to several experts, the automation of intellectual labour is on the way to create an irresolvable dynamic of technical unemployment if radical political and economic changes are not made in the near future (Smith and Anderson 2014). These radical changes will only be possible if the struggle against the neoliberal shipwrecking of universities within information capitalism is articulated, at the same time, against both "a jobless economy and a citizenless democracy" (McChesney and Nichols 2016).

\section{References}

Adams, Richard. 2015. Government Plan to Allow 'Better' Universities to Raise Fees. The Guardian, November 6. Accessed 13 January 2018. www.theguardian.com/education/2015/nov/06/government-plan-to-allow-betteruniversities-to-raise-fees

Adorno, Theodor W. and Max Horkheimer. 2002. Dialectic of Enlightenment. Stanford: Stanford University Press.

Althusser, Louis. 1976. Positions 1964-1975. Paris: Éditions sociales.

Andersen, Chris. 2008. The End of Theory: The Data Deluge Makes the Scientific Method Obsolete. Wired, August 23. Accessed 13 January 2018. https://www.wired.com/2008/06/pb-theory

Baran, Paul A. and Paul M. Sweezy. 1966. Monopoly Capital: An Essay on the American Economic and Social Order. New York: Monthly Review Press.

Barbrook, Richard and Andy Cameron. 1996. The Californian Ideology. Science as Culture 26 (1): 44-72.

Baudelot, Christian and Roger Establet. 1971. L'école capitaliste en France. Paris: Éditions Maspero.

Becker, Gary. 1964. Human Capital: A Theoretical and Empirical Analysis. Chicago: University of Chicago Press.

Bell, Daniel. 1973. The Coming of Post-Industrial Society: A Venture in Social Forecasting. New York: Basic Books.

Berle, Adolf and Gardner C. Means. 1968. The Modern Corporation and Private Property. New York: Brace \& World. 
Bichler, Shimson and Jonathan Nitzan. 2009. Capital as Power: A Study of Order and Creorder. London: Routledge.

Bissonnette, Jean François and Christian Laval. 2017. Gambling with "Human Capital": On the Speculative Logic of the "Knowledge Economy". World Social and Economic Review of Contemporary Policy Issues 8: 6-17.

Boltanski, Luc and Ėve Chiapello. 1999. Le nouvel esprit du capitalism. Paris: Gallimard.

Bourdieu, Pierre and Jean-Claude Passeron. 1990. Reproduction in Education: Society and Culture. Thousand Oaks: SAGE.

Bowles, Samuel and Herbert Gintis. 1976. Schooling in Capitalist America: Educational Reform and the Contradictions of Economic Life. New York: Basic Books.

Braverman, Harry. 1974. Labor and Monopoly Capital: The Degradation of Work in the Twentieth Century. New York: Monthly Review Press.

Bryan, Dick and Michael Rafferty. 2013. Fundamental Value: A Category in Transformation. Economy and Society 42 (1): 130-153.

Bryan, Dick, Randy Martin, Mike Rafferty. 2009. Financialization and Marx: Giving Labor and Capital a Financial Makeover. Review of Radical Political Economics 41 (4): 458-472.

Burnham, James. 1960. The Managerial Revolution. Bloomington: Indiana University Press.

Callon, Michel. 1988. La Science et ses réseaux. Genèse et circulation des faits scientifiques. Paris: La Découverte.

Castells, Manuel. 1996. The Rise of the Network Society. The Information Age: Economy, Society and Culture, Vol. I. Oxford: Blackwell.

Castoriadis, Cornelius. 1997. The Imaginary Institution of Society. Cambridge: MIT Press.

Christensen, Clayton and Henry Eyring. 2011. The Innovative University: Changing the DNA of Higher Education from the Inside Out. San Francisco: Jossey-Bass.

Cohen, Lizabeth. 2003. A Consumer's Republic: The Politics of Mass Consumption in Postwar America. New York: Knopf.

Collectif ACIDES. 2015. Arrêtons les frais! Pour un enseignement supérieur gratuit et émancipateur. Paris: Raisons d'agir.

Cox, Robert W. 1987. Production, Power and World Order. Social Forces in the Making of History. New York: Columbia University Press.

Cruickshank, Justin. 2016. Putting Business at the Heart of Higher Education: On Neoliberal Interventionism and Audit Culture in UK Universities. Open Library of Humanities 2 (1). Accessed July 28, 2017. https://olh.openlibhums.org/article/10.16995/olh.77

Department for Business, Innovation and Skills. 2011. Estimating the Value to the UK of Education Exports. London: BIS Research Paper. Accessed July 28, 2017. https://www.gov.uk/government/uploads/system/uploads/attachment data/file/32395/11980-estimating-value-of-education-exports.pdf

Dostaler, Gilles and Michel Beaud. 1995. Economic Thought Since Keynes: A History and Dictionary of Major Economists. Aldershot: Edward Elgar.

Freitag, Michel. 2002. The Dissolution of Society within the 'Social'. European Journal of Social Theory 5 (2): 175-198.

Freitag, Michel. 1998. Le naufrage de l'université et autres essais d'épistémologie politique. Montreal: Éditions Nota Bene.

Friedman, Milton. 2002/1962. Capitalism and Freedom. Chicago: University of Chicago Press.

Fuchs, Christian. 2013. Digital Labour and Karl Marx. New York: Routledge.

Galbraith, John Kenneth. 1967. The New Industrial State. Boston: Houghton Mifflin.

Gibbons, Michael. 1997. Higher Education Relevance in the $21^{\text {st }}$ Century. Washington: World Bank.

Gibbons, Michael, Camille Limoges, Helga Nowotny, Simon Schwartzman, Peter Scott and Martin Trow. 1994. The New Production of Knowledge: The Dynamics of Science and Research in Contemporary Societies. Thousand Oaks: SAGE. 
Gillies, Donald. 2011. Agile Bodies: A New Imperative in Neoliberal Governance. Journal of Education Policy 26 (2): 207-223.

Giroux, Henry A. 2011. Once More, with Conviction: Defending Higher Education as a Public Good. Qui Parle: Critical Humanities and Social Sciences 20 (1): 117-135.

Hall, Gary. 2016. The Uberification of the University. Minneapolis: University of Minnesota Press.

Hardt, Michael and Antonio Negri. 2000. Empire. Cambridge: Harvard University Press.

Harvey, David. 2003. The New Imperialism. New York: Oxford University Press.

Hassan, Robert. 2017. The Worldly Space: The Digital University in Network Time. British Journal of Sociology of Education 38 (1): 72-82.

Hayek, Friedrich. 1945. The Use of Knowledge in Society. American Economic Review 35: 519-530.

Innis, Harold. 1950. Empire and Communications. Oxford: Clarendon Press.

Jameson, Frederic. 1991. Postmodernism, Or, the Cultural Logic of Late Capitalism. Durham: Duke University Press.

Jessop, Bob. 2017. Varieties of Academic Capitalism and Entrepreneurial Universities. Higher Education 73 (6): 853-870.

Larsen, Neil, Mathias Nilges, Josh Robinson and Nicholas Brown, eds. 2014. Marxism and the Critique of Value. Chicago: MCM' Books.

Laval, Christian, Francis Vergne, Pierre Clément and Guy Dreux. 2011. La nouvelle école capitaliste. Paris: La Découverte.

Lipuma, Edward and Benjamin Lee. 2005. Financial Derivatives and the Rise of Circulation. Economy and Society 34 (3): 404-427.

Lohoff, Ernst and Norbert Trenkle. 2014. La grande dévalorisation. Fécamp: Post-éditions.

Lukàcs, György. 1975. History and Class Consciousness. London: Merlin.

Lyotard, Jean-François. 1984. The Postmodern Condition: A Report on Knowledge. Minneapolis: University of Minnesota Press.

Mandel, Ernest. 1975. Late Capitalism. London: Humanities Press.

Manzerolle, Vincent and Atle Mikkola Kjøsen. 2012. The Communication of Capital: Digital Media and the Logic of Acceleration. tripleC 10 (2): 214-229.

Marcuse, Herbert. 1964. One-Dimensional Man: Studies in the Ideology of Advanced Industrial Society. Boston: Beacon Press.

Marshall, T.H. 1963. Class, Citizenship and Social Development. Chicago: Chicago University Press.

Martin, Éric. 2016. L'université globalisée. Transformations institutionnelles et internationalisation de l'enseignement supérieur. Montreal: Institut de recherche et d'informations socio-économiques. Accessed July 28, 2017. http://iris-recherche.qc.ca/publications/udem

Martin, Éric. 2011. La jeunesse chilienne contre l'éducation privée. Montreal: Institut de recherche et d'informations socio-économiques. Accessed July 28, 2017. http://irisrecherche.qc.ca/blogue/la-jeunesse-chilienne-contre-leducation-privee

Martin, Éric and Maxime Ouellet. 2014. La tyrannie de la valeur. Débats pour le renouvellement de la théorie critique. Montreal: Écosociété.

Martin, Éric and Maxime Ouellet. 2012. La gouvernance des universités dans l'économie du savoir: Entre marchandisation et financiarisation. In Leurres de la qualité? edited by Bruno Leclercq, 169-194. Paris: L'Harmattan.

Martin, Éric and Maxime Ouellet. 2011. Université Inc. Mythes à déconstruire sur la hausse des frais de scolarité et l'économie du savoir. Montreal: Lux.

Marx, Karl. 1969. Grundrisse: Fondements de la critique de la critique de l'économie politique, Vol. 3. Paris: Éditions Anthropos.

Marx, Karl. 1844. On the Jewish Question. Accessed July 28, 2017. https://www.marxists.org/archive/marx/works/1844/jewish-question

Mattelart, Armand. 1991. Advertising International: The Privatization of Public Space. New York: Routledge. 
May, Christopher. 2000. A Global Political Economy of Intellectual Property Right: The New Enclosures. London: Routledge.

McChesney, Robert and John Nichols. 2016. People Get Ready: The Fight Against a Jobless Economy and a Citizenless Democracy. New York: Nation Books.

Merton, Robert K. 1942. The Normative Structure of Science. In The Sociology of Science, edited by Robert K. Merton, 267-278. Chicago: The University of Chicago Press.

Mirowski, Philip. 2013. Never Let a Serious Crisis Go to Waste: How Neoliberalism Survived the Financial Meltdown. London: Verso.

Mirowski, Philip. 2011. Science Mart: Privatizing American Science. Cambridge: Harvard University Press.

Mirowski, Philip. 2000. Machine Dreams: How Economics Becomes a Cyborg Science. Cambridge: Cambridge University Press.

Mouhoud, El Mouhoub and Dominique Plihon. 2009. Le savoir et la finance. Paris: La Découverte.

Noble, David. 1998. Digital Diploma Mills. The Automation of Higher Education. First Monday 3 (1). Accessed July 28, 2017. http://journals.uic.edu/ojs/index.php/fm/article/view/569/490

Noble, David. 1977. America By Design: Science, Technology and the Rise of Corporate Capitalism. New York: Alfred A. Knopf.

OECD and World Bank. 2007. Cross-Border Tertiary Education: A Way Towards Capacity Development. Paris: OECD Publications. Accessed July 28, 2017. https://openknowledge.worldbank.org/handle/10986/6865

Orsi, Fabienne and Benjamin Coriat. 2006. The New Role and Status of Intellectual Property Rights in Contemporary Capitalism. Competition \& Change 10(2): 162-179.

Ouellet, Maxime. 2016. La révolution culturelle du capital. Le Capitalisme cybernétique dans la société globale de l'information. Montreal: Écosociété.

Ouellet, Maxime. 2015. Revisiting Marx's Value Theory: Elements of a Critical Theory of Immaterial Labor in Informational Capitalism. The Information Society 31 (1): 20-27.

Papadopoulos, George S. 1994. Education 1960-1990: The OECD Perspective. Paris: OECD.

Postone, Moishe. 1999. Contemporary Historical Transformations: Beyond Postindustrial Theory and Neo-Marxism. Current Perspectives in Social Theory 19: 3-53.

Postone, Moishe. 1993. Time, Labor and Social Domination: A Reinterpretation of Marx's Critical Theory. Cambridge: Cambridge University Press.

Prado, Plinio. 2009. Le principe université. Paris: Éditions Lignes.

Readings, Bill. 1997. The University in Ruins. Cambridge: Harvard University Press.

Robins, Kevin and Frank Webster, eds. 2003. The Virtual University? Knowledge, Markets, and Management. Oxford: Oxford University Press.

Rupert, Mark. 2000. Ideologies of Globalization: Contending Visions of a New World Order. London: Routledge.

Salmi, Jamil. 2009. Le défi d'établir des universités de rang mondial. Washington: World Bank. Accessed July 28, 2017. http://siteresources.worldbank.org/EDUCATION/Resources/2782001099079877269/547664-1099079956815/547670-1237305262556/WorldClass Universities French.pdf

Schwab, Klaus. 2016. The Fourth Industrial Revolution. Geneva: World Economic Forum.

Singer, Natasha. 2017. How Google Took Over the Classroom. New York Times, May 13. Accessed 13 January 2018. https://www.nytimes.com/2017/05/13/technology/googleeducation-chromebooks-schools.html

Sklair, Leslie. 1991. Sociology of the Global System. Hertfordshire: Harvester Wheatsheaf.

Slaughter, Sheila and Larry L. Leslie. 1999. Academic Capitalism: Politics, Policies, and the Entrepreneurial University. Baltimore: Johns Hopkins University Press. 
Smith, Aaron and Janna Anderson. 2014. Al, Robotics, and the Future of Jobs. Pew Research Center, August 6. Accessed 13 January 2018. http://www.pewinternet.org/2014/08/06/future-of-jobs

Smythe, Dallas W. 1977. Communications: Blindspot of Western Marxism. Canadian Journal of Political and Social Theory 1 (3): 1-28.

Stiegler, Bernard. 2012. États de choc. Bêtise et savoir au XXle siècle. Paris: Mille et une nuits.

The Economist. 2011. Higher Education: The Latest Bubble? The Economist, April 13. Accessed 13 January 2018. http://www.economist.com/blogs/schumpeter/2011/04/higher education

UK Government. 2013. Press Release: New Push to Grow UK's £17.5 Billion Education Exports Industry. Accessed July 28, 2017. https://www.gov.uk/government/news/new-pushto-grow-uks-175-billion-education-exports-industry

Vercellone, Carlos. 2004. Division internationale du travail, propriété intellectuelle et développement à l'heure du capitalisme cognitive. Géographie Économie Société 6 (4): 359381.

World Economic Forum. 2016. The Future of Jobs: Employment, Skills and Workforce Strategy for the Fourth Industrial Revolution. Geneva: World Economic Forum. Accessed July 28, 2017. http://www3. weforum.org/docs/WEF Future of Jobs.pdf

Zeller, Christian. 2008. From the Gene to the Globe: Extracting Rents Based on Intellectual Property. Review of International Political Economy 15 (1): 86-115.

Zhang, Jie. 2014. Developing Excellence: Chinese University Reform in Three Steps. Nature, October 15. Accessed 13 January 2018. www.nature.com/news/developing-excellencechinese-university-reform-in-three-steps-1.16128

\section{About the Authors}

Maxime Ouellet

Maxime Ouellet is a professor at the Media School of the Université du Québec à Montréal (UQAM). He co-wrote and directed, with Éric Martin, University Inc. Myths About Rising Tuition Fees and the Knowledge Economy (Lux 2011) and The Tyranny of Value. Debates for the Renewal of Critical Theory (Ecosociété 2014). His most recent essay is entitled The Cultural Revolution of Capital. Cybernetic Capitalism in the Global Information Society (Ecosociété 2016).

Éric Martin

Éric Martin is a philosophy professor in Cégep Édouard-Montpetit (Longueuil, QC). He cowrote and directed, with Maxime Ouellet, University Inc. Myths About Rising Tuition Fees and the Knowledge Economy (Lux 2011) and The Tyranny of Value. Debates for the Renewal of Critical Theory (Ecosociété 2014). 